\title{
Garden and food waste co-fermentation for biohydrogen and biomethane production in a two-step hyperthermophilic-mesophilic process
}

\author{
A.A. Abreu, F. Tavares, M.M. Alves, A.J. Cavaleiro, M.A. Pereira* \\ Centre of Biological Engineering, University of Minho, 4710-057 Braga, Portugal
}

\section{A R T I C L E I N F O}

\section{Keywords:}

Garden waste

Food waste

Co-fermentation

Caldicellulosiruptor saccharolyticus

Biochemical methane potential

\begin{abstract}
A B S T R A C T
Co-fermentation of garden waste (GW) and food waste (FW) was assessed in a two-stage process coupling hyperthermophilic dark-fermentation and mesophilic anaerobic digestion (AD). In the first stage, biohydrogen production from individual substrates was tested at different volatile solids (VS) concentrations, using a pure culture of Caldicellulosiruptor saccharolyticus as inoculum. FW concentrations (in VS) above $2.9 \mathrm{~g} \mathrm{~L}^{-1}$ caused a lag phase of 5 days on biohydrogen production. No lag phase was observed for GW concentrations up to $25.6 \mathrm{~g} \mathrm{~L}^{-1}$. In the co-fermentation experiments, the highest hydrogen yield $\left(46 \pm 1 \mathrm{~L} \mathrm{~kg}^{-1}\right)$ was achieved for GW:FW $90: 10 \%(w / w)$. In the second stage, a biomethane yield of $682 \pm 14 \mathrm{~L} \mathrm{~kg}^{-1}$ was obtained using the end-products of GW:FW 90:10\% co-fermentation. The energy generation predictable from co-fermentation and AD of GW:FW 90:10\% is $0.5 \mathrm{MJ} \mathrm{kg}^{-1}$ and $24.4 \mathrm{MJ} \mathrm{kg}^{-1}$, respectively, which represents an interesting alternative for valorisation of wastes produced locally in communities.
\end{abstract}

\section{Introduction}

Overexploitation of fossil fuels has contributed for a rapid depletion of natural energy sources, causing also environmental pollution and climate changes. The development of alternative energy sources has thus been pursued, with a special focus on renewable and low-carbon fuels. Biomass-derived fuels (biofuels) have an important role in the transition to more sustainable and green energy-based societies, and its production has been increasing worldwide over the last decades.

Comparing with other biofuels, biohydrogen has the highest energy content per unit of weight and it enables clean power generation, since it is a carbon-free fuel which does not emit greenhouse gas after its combustion/oxidation (Sivagurunathan et al., 2017). Major concerns on the sustainability of many first-generation biofuels turned the attention to second-generation biofuels, which have the potential to consume waste residues and reduce $\mathrm{CO}_{2}$ emissions (IEA Bioenergy, 2009). In this framework, biohydrogen fermentation processes have evolved as clean and cost-effective solutions relying on the activity of hydrogen-producing microorganisms, and on the use of agricultural or forestry residues. (Cheng et al., 2011; Ren et al., 2011; Wang et al., 2018a,b).

Among the possible different feedstock for fermentative biohydrogen production, food waste (FW) is one of the most abundant organic wastes, representing $15-63 \%$ of total municipal solid wastes (Yun et al., 2018). FW is being targeted as a promising carbon source due to its characteristics, such as high moisture content (72-85\%), high organic concentration (i.e. $20-346 \mathrm{~g} \mathrm{~L}^{-1}$ as chemical oxygen demand (COD), 26-143 $\mathrm{g} \mathrm{L}^{-1}$ as carbohydrates) and high carbon to nitrogen ratio (9-21) (Elbeshbishy et al., 2011; Hwang et al., 2011; Braguglia et al., 2018; Yun et al., 2018). Lignocellulosic agricultural wastes such as rice straw, wheat straw, barney straw and corn stalks have also received special attention concerning biohydrogen production due to their widespread abundance and wide availability (Datar et al., 2007; Cao et al., 2009; Kongjan and Angelidaki, 2010; Lo et al., 2010; Urbaniec and Bakker, 2015; Sivagurunathan et al., 2017). In general, biohydrogen production from these wastes depend on its chemical composition, pre-treatment methods, the microorganisms used as inoculum and the process conditions (Urbaniec and Bakker, 2015). For example, higher hydrogen yields and production rates are generally accomplished by dark fermentation processes performed at thermophilic or hyperthermophilic conditions, relatively to mesophilic processes (Urbaniec and Bakker, 2015). The significance of biohydrogen production was also shown for locally relevant wastes, e.g. oat straw hydrolysate (Arriaga et al., 2011) and mushroom farm waste hydrolysate (Li et al., 2011). Among agricultural wastes, garden waste (GW) appears as a very attractive raw material for biohydrogen production (Boldrin, 2009; Shi et al., 2013; Abreu et al., 2016), and its production has been increasing considerably with rapid urbanization worldwide.

\footnotetext{
* Corresponding author at: Departamento de Engenharia Biológica, Universidade do Minho, Campus de Gualtar, $4710-057$ Braga, Portugal.

E-mail addresses: madalena.alves@deb.uminho.pt (M.M. Alves), acavaleiro@deb.uminho.pt (A.J. Cavaleiro), alcina@deb.uminho.pt (M.A. Pereira).
} 
GW typically includes different fractions such as grass clippings, hedge cuttings, small branches, leaves and wood debris, and consists primarily of renewable polysaccharides and lignin (Shi et al., 2013; Abreu et al., 2016).

In the last years, several studies using FW or GW for biohydrogen production were performed (Cheng et al., 2011; Pan et al., 2013; Yasin et al., 2013; Nissilä et al., 2014; Abreu et al., 2016; Algapani et al., 2018; Ghimire et al., 2018), but the potential utilization of both wastes simultaneously by co-fermentation was not evaluated. In GW the fermentable sugars are present in complex and hardly digestible forms, while FW is an easier biodegradable substrate which is also a source of nitrogen (that is lacking in GW). Nevertheless, the presence of lipids and proteins in FW composition is generally associated with a lower hydrogen production than carbohydrate-rich organic wastes (Bharathiraja et al., 2016). Co-fermentation of FW and GW may contribute to overcome the disadvantages of single fermentation and potentially improve the hydrogen production from these wastes.

Fermentative hydrogen production involves either facultative and strict anaerobic bacteria (De Gioannis et al., 2013). Extreme thermophiles belonging to the genera Caldicellulosiruptor and Thermotoga are commonly referred as very efficient $\mathrm{H}_{2}$ producers (Pawar and van Niel, 2013). Among Caldicellulosiruptor genera, the interest on C. saccharolyticus is increasing due to the capacity to metabolize various carbon sources ranging from simple sugars to complex lignocellulosic materials (Willquist et al., 2010). C. saccharolyticus is reported to approach the theoretical maximum $\mathrm{H}_{2}$ yield from glucose of $4 \mathrm{~mol} \mathrm{~mol}^{-1}$ and is referred as relatively insensitive to high $\mathrm{pH}_{2}$ (Willquist et al., 2010). Moreover, C. saccharolyticus lacks carbon catabolite repression, enabling the simultaneous fermentation of hexoses and pentoses (Bielen et al., 2013).

Biohydrogen dark fermentation can be coupled with a second stage process, where the fermentation end products, rich in volatile fatty acids (VFA), can be converted to methane through an anaerobic digestion process, coupling energy carrier generation and waste treatment. After upgrading, the generated biomethane can be used directly as renewable fuel or fed into the established natural gas grid, thus replacing fossil fuels and contributing for reducing the greenhouse gas emissions. The two-step approach for hydrogen and methane production has been tested with different substrates, from pure sugars to diverse feedstocks such as municipal, agricultural and food industry wastes (Wang and Zhao, 2009; Liu et al., 2013; Costa et al., 2015; Abreu et al., 2016). However, only few studies were reported on hydrogen and methane production from more than one residue in co-fermentation, e.g. FW + pulp and paper sludge (Lin et al., 2013) and FW + waste activated sludge (Liu et al., 2013). Furthermore, there are no studies describing possible solutions for the treatment and valorisation of both GW and FW. This is important because these two types of wastes account for a significant fraction of municipal solid wastes and therefore, considering the amounts produced, may constitute a relevant source for bioenergy production.

The main objective of this study is the optimization of bioenergy production from food waste and garden waste, by co-fermentation using an efficient hydrogen-producing culture of $C$. sacharolyticus coupled with methane production from the end-products of biohydrogen co-fermentation. Hyperthermophilic conditions were selected for the first fermentation step because higher wastes solubilization and biohydrogen production are generally achieved, relatively to mesophilic conditions. The methanogenic step was then performed at mesophilic temperatures, since heat will be transferred from the first to the second step with the digestate and is expected to be sufficient to exempt the heating of the anaerobic digester.

\section{Materials and methods}

\subsection{Food and garden waste characterization}

Samples of milled food waste (FW) were collected during 5 days in the University of Minho canteen, at Campus de Gualtar, Braga, Portugal, and stored at $-20^{\circ} \mathrm{C}$. A composed substrate was then prepared by mixing and homogenizing all the samples. Garden waste (GW) was composed by grass and small bushes collected by the municipal waste management company AGERE, Braga, Portugal. GW was dried and milled into pieces smaller than $5 \mathrm{~mm}$. FW and GW were characterized in terms of total and soluble COD, total solids (TS), volatile solids (VS), ash content, total Kjeldahl nitrogen (TKN), ammonium $\left(\mathrm{NH}_{4}{ }^{+}\right)$, fat content, proteins, Klason lignin, glucan and xylan content. Soluble COD of FW and GW was also analysed after autoclaving $\left(121^{\circ} \mathrm{C}\right.$ and $0.1 \mathrm{MPa}$ for $20 \mathrm{~min}$ ), that functioned as thermal and pressure pretreatment.

\subsection{Biohydrogen production from $F W$ and $G W$}

\subsubsection{Inoculum and medium composition}

Caldicellulosiruptor saccharolyticus DSM 8903 was obtained from the Deutsche Sammlung von Mikroorganismen und Zellkulturen (DSMZ, Germany). The culture medium consisted of (per $\mathrm{L}$ ) $\mathrm{KH}_{2} \mathrm{PO}_{4} 0.75 \mathrm{~g}$, $\mathrm{K}_{2} \mathrm{HPO}_{4} 1.5 \mathrm{~g}, \mathrm{MgCl}_{2} \cdot 6 \mathrm{H}_{2} \mathrm{O} 0.33 \mathrm{~g}, \mathrm{NH}_{4} \mathrm{Cl} 0.4 \mathrm{~g}$, yeast extract $1.0 \mathrm{~g}$, $\mathrm{FeCl}_{3} \cdot 6 \mathrm{H}_{2} \mathrm{O} 2.5 \mathrm{mg}$, NaCl $0.9 \mathrm{~g}$, trypticase $2 \mathrm{~g}$, SL-10 (medium 320 DSMZ) trace elements $1 \mathrm{~mL}$, and resazurin $0.5 \mathrm{mg}$. The culture medium was supplemented with $50 \mathrm{mmol} \mathrm{L}^{-1}$ 4-morpholine propanesulfonic acid (MOPS) to increase the buffering capacity and was reduced with $0.75 \mathrm{~g} \mathrm{~L}^{-1}$ cysteine- $\mathrm{HCl}$ monohydrated. Cellobiose $\left(2 \mathrm{~g} \mathrm{~L}^{-1}\right)$ was used as the carbon source and the medium was made anoxic by boiling and flushing with $100 \% \mathrm{~N}_{2}$. C. saccharolyticus was grown at $70^{\circ} \mathrm{C}$ with agitation (90 rpm). After reaching an optical density (OD) at $620 \mathrm{~nm}$ of $0.2-0.3$ the culture was used as inoculum for the subsequent batch assays.

\subsubsection{Biohydrogen production assays}

Biohydrogen production from FW and GW was assessed in $160 \mathrm{~mL}$ serum bottles containing $50 \mathrm{~mL}$ of phosphate-buffered medium $\left(20 \mathrm{mmol} \mathrm{L}^{-1}\right)$ supplemented with MOPS $\left(50 \mathrm{mmol} \mathrm{L}^{-1}\right)$ and flushed with $\mathrm{N}_{2}(100 \%)$, as described in Section 2.2.1. Different waste VS concentrations were added to the assays: $0.7,1.5,2.9$ and $4.4 \mathrm{~g} \mathrm{~L}^{-1}$ of FW; 4.3, 8.5, 17.0 and $25.6 \mathrm{~g} \mathrm{~L}^{-1}$ of GW. The bottles were then autoclaved at $121{ }^{\circ} \mathrm{C}$ for $20 \mathrm{~min}$, thus functioning as a wastes pre-treatment. After autoclaving, yeast extract was added to a final concentration of $0.5 \mathrm{~g} \mathrm{~L}^{-1}$ and the medium was reduced with $0.75 \mathrm{~g} \mathrm{~L}^{-1}$ cysteine- $\mathrm{HCl}$ monohydrated. Finally, inoculation with $5 \mathrm{~mL}$ of pre-cultured $C$. saccharolyticus (OD at $620 \mathrm{~nm}$ of $0.2-0.3$ ) was performed and the bottles were incubated at $70{ }^{\circ} \mathrm{C}$ under agitation at $90 \mathrm{rpm}$. All the experiments were performed in quadruplicate and included controls (prepared without $C$. saccharolyticus) and blanks (inoculated with C. saccharolyticus but without waste). Production of hydrogen gas, soluble fermentation products and final $\mathrm{pH}$ were monitored. Cumulative hydrogen production values were corrected for standard temperature and pressure (STP) conditions $\left(0^{\circ} \mathrm{C}\right.$ and $\left.0.1 \mathrm{MPa}\right)$

\subsection{Hydrogen production by co-fermentation of FW and GW}

Co-fermentation assays were prepared as described above for the biohydrogen production assays (Section 2.2.2.), using different $\mathrm{GW}$ and FW ratios $(90: 10 \%, 50: 50 \%, 100: 0 \%$ and $0: 100 \% \mathrm{w} / \mathrm{w}$ in VS) with a final waste concentration (in VS) of $8.5 \mathrm{~g} \mathrm{~L}^{-1}$. All the experiments were performed in sextuplicate and included controls without waste and without $C$. saccharolyticus. Production of hydrogen gas, soluble fermentation products and final $\mathrm{pH}$ were monitored. Total and soluble COD were also analyzed at the end of the assays. 


\subsection{Biomethane production assays}

Anaerobic granular sludge from a brewery wastewater treatment plant was used as inoculum. The specific methanogenic activity (SMA) of this sludge, determined as described in Eiroa et al. (2012) and expressed in volume of methane produced at STP conditions per mass unit of VS of inoculum and time $\left(\mathrm{mL} \mathrm{g}^{-1} \mathrm{~d}^{-1}\right)$, was $118.1 \pm 1.2 \mathrm{~mL} \mathrm{~g}^{-1} \mathrm{~d}^{-1}$ and $540.2 \pm 49.9 \mathrm{~mL} \mathrm{~g}^{-1} \mathrm{~d}^{-1}$ in the presence of acetate $\left(30 \mathrm{mmol} \mathrm{L}^{-1}\right)$ and $\mathrm{H}_{2} / \mathrm{CO}_{2}(80 / 20 \% \mathrm{v} / \mathrm{v}, 1$ bar overpressure), respectively.

Methane production from the end-products of the co-fermentation tests (GW:FW of 90:10\%, 100:0\% and 0:100\%) was studied in batch assays performed according to the guidelines defined by Angelidaki et al. (2009). A total of $50 \mathrm{~mL}$ of the end-products of each co-fermentation assays were added to $600 \mathrm{~mL}$ serum bottles, containing $20 \mathrm{~g}$ (wet weight) of inoculum and $50 \mathrm{~mL}$ of basal medium containing $\mathrm{NaHCO}_{3}$ $\left(5 \mathrm{~g} \mathrm{~L}^{-1}\right)$. $\mathrm{pH}$ of the medium was corrected to 7.0-7.2. The vials were sealed and the headspace flushed with $\mathrm{N}_{2} / \mathrm{CO}_{2}(80: 20 \% \mathrm{v} / \mathrm{v})$. Before incubation, the medium was amended with $\mathrm{Na}_{2} \mathrm{~S} \cdot 9 \mathrm{H}_{2} \mathrm{O}$, to a final concentration of $1 \mathrm{mmol} \mathrm{L}^{-1}$. Blank assays to discount for the residual substrate present in the inoculum were performed, as well as controls with hydrolysate and without sludge. Additionally, a control with GW:FW 90:10\% (w/w in VS) without being subjected to the first step of dark fermentation was performed. All the assays were made in triplicate and were incubated at $37^{\circ} \mathrm{C}$ with agitation $(90 \mathrm{rpm})$. The methane accumulated in the headspace of the closed bottles was measured, the values were corrected for STP conditions and converted to its equivalent COD (considering that $1 \mathrm{~g}$ of COD generates $0.35 \mathrm{~L}$ of methane at STP conditions). Biochemical methane potential (BMP) was defined by the volume of methane produced (L@STP) per unit of COD ( $\mathrm{kg}$ ) of substrate added to the assay.

\subsection{Analytical methods}

Determination of lignin, xylan and glucan was performed according to Sluiter et al. (2008). TKN, $\mathrm{NH}_{4}{ }^{+}$, TS, VS and ash content were measured according to standard methods (APHA et al., 1998). Total and soluble COD were analysed spectrophotometrically using standard kits (Hach Lange, Düsseldorf, Germany). Sample filtration was performed prior to soluble COD (CODs) determination. Lipids concentration was quantified as described by Bligh and Dyer (1959). Protein content was determined according to the method established by FAO (FAO, 2003). Hydrogen concentration in the gas phase was determined by gas chromatography (GC) using a Bruker Scion 456 Chromatograph (Bruker, Massachusetts, USA) equipped with a molsieve column (MS$13 \mathrm{x} 80 / 100 \mathrm{mesh}$ ) and a thermal conductivity detector. Argon $\left(30 \mathrm{~mL} \mathrm{~min}^{-1}\right)$ was used as the carrier gas. The injector, detector and column temperatures were 100,130 , and $35^{\circ} \mathrm{C}$ respectively. Methane content in the biogas was analysed by GC (Chrompack 9000) equipped with a flame ionization detector (FID) and a $2 \mathrm{~m} \times 1 / 8^{\prime \prime}$ Chromosorb 101 (80-120 mesh) column, using nitrogen as carrier gas $\left(30 \mathrm{~mL} \mathrm{~min}^{-1}\right)$; column, injector, and detector temperatures were 35 , 110 , and $220^{\circ} \mathrm{C}$, respectively. VFA, lactic acid, alcohols and sugars were determined by high performance liquid chromatography (Jasco, Tokyo, Japan) with a Chrompack column $(6.5 \times 30 \mathrm{~mm})$ and sulfuric acid $\left(5 \mathrm{mmol} \mathrm{L}^{-1}\right)$ as mobile phase at a flow rate of $0.9 \mathrm{~mL} \mathrm{~min}^{-1}$. Column temperature was set at $80^{\circ} \mathrm{C}$. Detection of VFA and lactic acid was made using an ultraviolet (UV) detector at $210 \mathrm{~nm}$; for sugars a refractive index (RI) detector was used.

\subsection{Data analysis}

The modified Gompertz equation (Eq. (1), Zwietering et al., 1990) was used to describe the progress of cumulative hydrogen production obtained from the batch experiments.
Table 1

Results of food waste and garden waste characterization.

\begin{tabular}{|c|c|c|}
\hline Parameters & Food waste (FW) & Garden waste (GW) \\
\hline Total COD (mg g ${ }^{-1}$ ) & $160 \pm 11$ & $934 \pm 15$ \\
\hline Soluble COD $\left(\mathrm{mg} \mathrm{g}^{-1}\right)$ & $45 \pm 0$ & $174 \pm 1$ \\
\hline $\mathrm{TS}\left(\mathrm{mg} \mathrm{g}^{-1}\right)$ & $168 \pm 4$ & $914 \pm 1$ \\
\hline VS ( $\left.\mathrm{mg} \mathrm{g}^{-1}\right)$ & $148 \pm 1$ & $847 \pm 2$ \\
\hline Ash content $\left(\mathrm{mg} \mathrm{g}^{-1}\right)$ & $20 \pm 4$ & $67 \pm 2$ \\
\hline $\mathrm{TKN}\left(\mathrm{mg} \mathrm{N} \mathrm{g}^{-1}\right)$ & $8.1 \pm 0.5$ & n.d. \\
\hline Ammonium (mg N-NH${ }_{4} \mathrm{~g}^{-1}$ ) & $1.6 \pm 0.9$ & n.d. \\
\hline Fat content $\left(\mathrm{mg} \mathrm{g}^{-1}\right)$ & $48 \pm 3$ & n.a. \\
\hline Protein $\left(\mathrm{mg} \mathrm{g}^{-1}\right)$ & $46 \pm 3$ & n.d. \\
\hline Klason Lignin (\% VS) & n.a. & $32.1 \pm 0.3$ \\
\hline Glucan (\% VS) & n.a. & $23.5 \pm 5.9$ \\
\hline Xylan (\% VS) & n.a. & $8.8 \pm 0.9$ \\
\hline
\end{tabular}

n.d. - not detected; n.a. - not analyzed.

* Abreu et al., 2016.

$\mathrm{H}(\mathrm{t})=\mathrm{P} \cdot \exp \left\{-\exp \left[\frac{R_{m} \cdot e}{P}(\lambda-t)+1\right]\right\}$

$\mathrm{H}(\mathrm{t})=$ cumulative hydrogen production $\left(\mathrm{mL} \mathrm{g}^{-1}\right) ; \mathrm{P}=$ maximum hydrogen production $\left(\mathrm{mL} \mathrm{g}^{-1}\right) ; \mathrm{R}_{\mathrm{m}}=$ hydrogen production rate $\left(\mathrm{mL} \mathrm{g}^{-1}\right.$ day $\left.^{-1}\right) ; \mathrm{e}=2.71828 \ldots ; \lambda=$ lag-phase time (d); $\mathrm{t}=$ time (d). All parameters were expressed per amount $(\mathrm{g})$ of waste VS added initially. Data analysis was performed using Sigma Plot for Windows 10.0 software (Systat Software Inc, Germany).

\section{Results and discussion}

\subsection{Biohydrogen production from $F W$ and $G W$}

The characteristics of the studied wastes are presented in Table 1. The two wastes presented different moisture content (approx. 9\% and $83 \%$ humidity for GW and FW, respectively), but similar organic matter concentration (expressed as the ratio between total COD and TS), i.e. around $1 \mathrm{gg}^{-1}$. Glucan (glucose, cellobiose, cellulose) and xylan (xylose and hemicellulose) content of GW totalize $32 \%$ of the volatile solids, and the Klason lignin content represents $32.1 \pm 0.3 \%$ of the VS. After autoclaving, soluble COD increased up to $23 \%$ and $46 \%$ of the total COD for GW and FW, respectively.

Biohydrogen was produced from the autoclaved FW and GW, at all the concentrations tested (Fig. 1), while in blanks and controls only vestigial hydrogen amounts were detected $(<0.5$ and $<0.08 \mathrm{~mL}$, respectively). In general, for both wastes, volumetric hydrogen production increased with the increase of waste concentration (in VS). However, hydrogen yields $\left(\mathrm{Y}_{\mathrm{H} 2}\right)$ decreased with the increase of waste VS concentrations, suggesting a possible inhibition by the substrate. $\mathrm{Y}_{\mathrm{H} 2}$ (expressed relatively to the amount of waste VS added initially) varied from $133.5 \pm 2.7 \mathrm{~mL} \mathrm{~g}^{-1}$ to $82.9 \pm 0.9 \mathrm{~mL} \mathrm{~g}^{-1}$ for the range of $\mathrm{FW}$ concentrations tested (0.7-4.4 $\mathrm{g} \mathrm{L}^{-1}$ in VS), and the lag phase preceding the onset of hydrogen production increased from 1 day to 5 days in the assays with FW concentrations of 2.9 and $4.4 \mathrm{~g} \mathrm{~L}^{-1}$ (Fig. 1a). Elbeshbishy et al. (2011) summarized the results from several studied performed with FW, and referred hydrogen yields between 57 and $250 \mathrm{~mL} \mathrm{~g}^{-1}$. Thus, the values obtained in this assay for FW are within the range reported in the literature. For GW, although no lag phase was observed for concentrations up to $25.6 \mathrm{~g} \mathrm{~L}^{-1}$ (Fig. 1b), $\mathrm{Y}_{\mathrm{H} 2}$ varied from $53.3 \pm 1.4$ to $15.3 \pm 0.1 \mathrm{~mL} \mathrm{~g}^{-1}$ for the range of concentrations tested (4.2-25.6 $\mathrm{g} \mathrm{L}^{-1}$ in VS). Slightly higher hydrogen production yields (around $80 \mathrm{mLg}^{-1}$ ) were obtained from GW by Abreu et al. (2016) when using pure cultures of the extreme thermophiles $C$. saccharolyticus or Caldicellulosiruptor bescii as inoculum, and co-culturing these two strains increased synergistically the hydrogen production yield up to $98 \mathrm{~mL} \mathrm{~g}^{-1}$. Values between 1 and $150 \mathrm{mLg}^{-1}$ have been reported in the literature for different agricultural wastes, as reviewed 


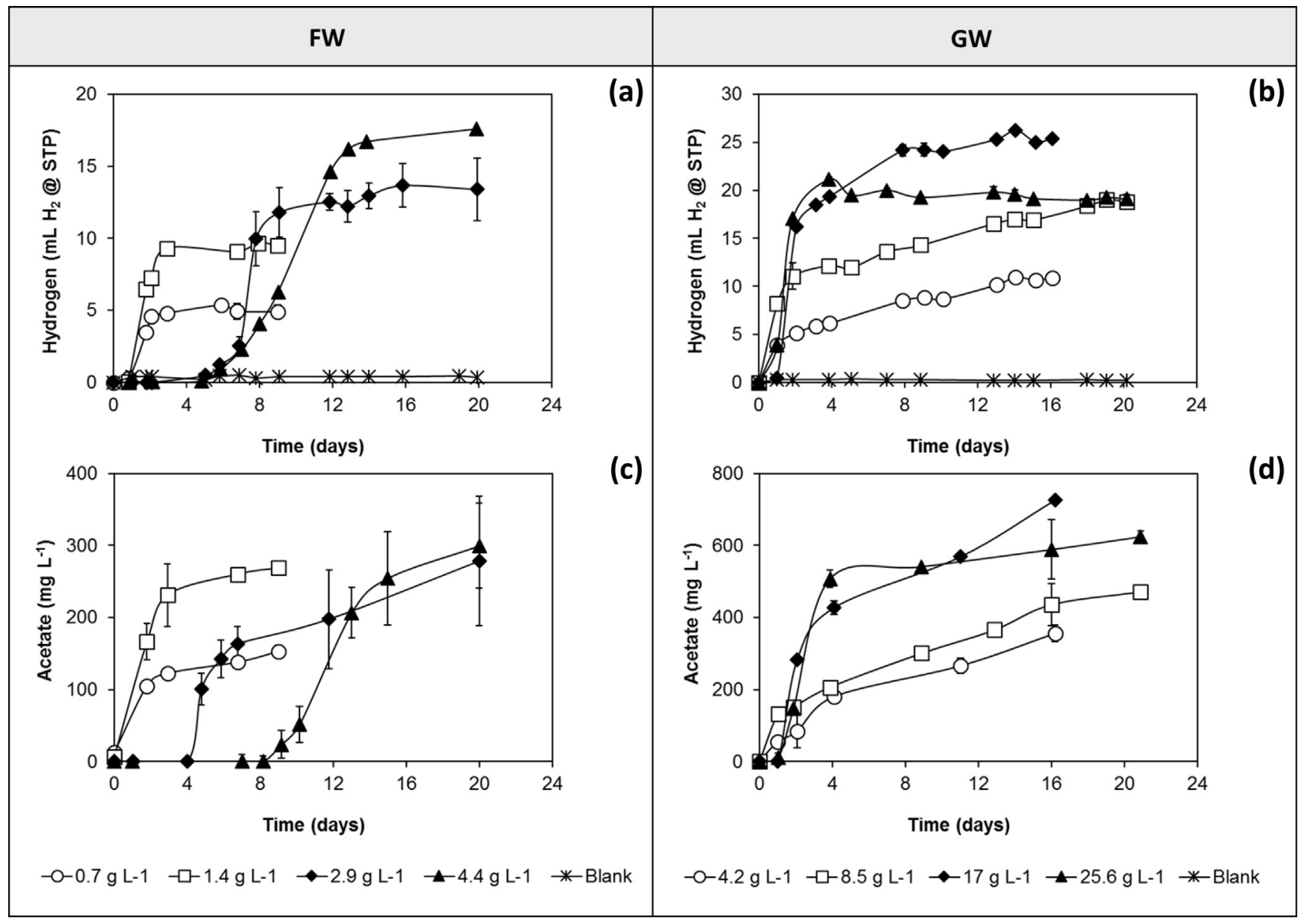

Fig. 1. Dark fermentation of FW and GW: cumulative biohydrogen production from FW (a) and GW (b); acetate production from FW (c) and GW (c).

by Guo et al. (2010), and our results fall within this range. In the case of FW, the potential inhibition by the substrate may be due to the release of ammonium and long chain fatty acids during the autoclaving pretreatment applied. These compounds are known to be potentially inhibitory to different anaerobic microorganisms, although no information is available on this topic for $C$. saccharolyticus. For GW, potentially formed by-products capable of inhibiting hydrogen production may include furan-derivatives (e.g. furfural), carbonic acids (methanoic acid, ethanoic acid and levulinic acid) or phenolic compounds, as previously reported for other lignocellulosic materials (Sivagurunathan et al., 2017). The inhibitory effects and threshold concentrations of these by-products were shown to be highly specific to the microorganisms used as inocula (Sivagurunathan et al., 2017).

Acetate was the only soluble fermentation product detected for both wastes (Fig. 1c, d). Acetate concentration increased with the added FW concentrations, up to a maximum of $300 \mathrm{mg} \mathrm{L}^{-1}$ (Fig. 1c), and for GW the highest acetate concentration $\left(725 \mathrm{mg} \mathrm{L}^{-1}\right)$ was obtained with $17 \mathrm{~g} \mathrm{~L}^{-1}$ (Fig. 1d), corresponding to the highest volumetric hydrogen production.

The COD conversion efficiency of the wastes, expressed in percentage, was calculated considering the amount of hydrogen and acetate produced, converted to its equivalent COD, and the amount of soluble or total COD of the waste added to each assay (Table 2). In the range of FW concentrations tested, $65-26 \%$ of the soluble COD and $30-12 \%$ of the total COD were converted to hydrogen + acetate. For GW this varied between 50 and $15 \%$ and $11-3 \%$ for soluble and total COD, respectively (Table 2). These results show that $C$. saccharolyticus was not being able to completely ferment the wastes, probably due to the presence of inhibitory compounds, as discussed before, and to possible
Table 2

COD conversion efficiency in the dark fermentation of FW and GW.

\begin{tabular}{llllll}
\hline Substrate & $\begin{array}{l}\text { Concentration } \\
\left(\mathrm{g} \mathrm{L}^{-1}\right)^{(\mathrm{a})}\end{array}$ & $\begin{array}{l}\mathrm{H}_{2}+\mathrm{Ac} \\
(\% \\
\mathrm{CODs}^{(\mathrm{b})}\end{array}$ & $\begin{array}{l}\mathrm{H}_{2}+\mathrm{Ac} \\
(\% \\
\mathrm{CODt}^{(\mathrm{b})}\end{array}$ & $\begin{array}{l}\mathrm{H}_{2}(\% \\
\mathrm{CODs})^{(\mathrm{c})}\end{array}$ & $\begin{array}{l}\mathrm{H}_{2}(\% \\
\mathrm{CODt}^{(\mathrm{c})}\end{array}$ \\
\hline $\mathrm{FW}$ & 0.7 & 65 & 30 & 20 & 9 \\
& 1.4 & 58 & 27 & 18 & 8 \\
& 2.9 & 33 & 15 & 13 & 6 \\
$\mathrm{GW}$ & 4.4 & 26 & 12 & 12 & 5 \\
& 4.2 & 50 & 11 & 15 & 3 \\
& 8.5 & 36 & 8 & 12 & 3 \\
& 17.0 & 27 & 6 & 9 & 2 \\
& 25.6 & 15 & 3 & 5 & 1
\end{tabular}

(a) Expressed in $\mathrm{g}$ of waste VS per litre.

(b) Represents the relation between the amount of hydrogen and acetate produced, converted to its equivalent COD, and the amount of soluble COD (CODs) or total COD (CODt) added to each assay.

(c) Represents the relation between the amount of hydrogen produced, converted to its equivalent COD, and the amount of soluble COD (CODs) or total COD (CODt) added to each assay.

difficulties in the hydrolysis of the wastes. Hydrogen production accounted for $20-12 \%$ and $15-5 \%$ of FW and GW soluble COD, respectively (Table 2), which represent only $9-5 \%$ (FW) and $3-1 \%$ (GW) of the total COD. Similar percentages of total COD conversion to hydrogen have been previously reported from fermentation of FW (Liu et al., 2013; Algapani et al., 2018; Yun et al., 2018). A significant fraction of the energy content of the substrate is generally kept in the end-products from the $\mathrm{H}_{2}$ fermentation, which justifies the interest in applying two- 

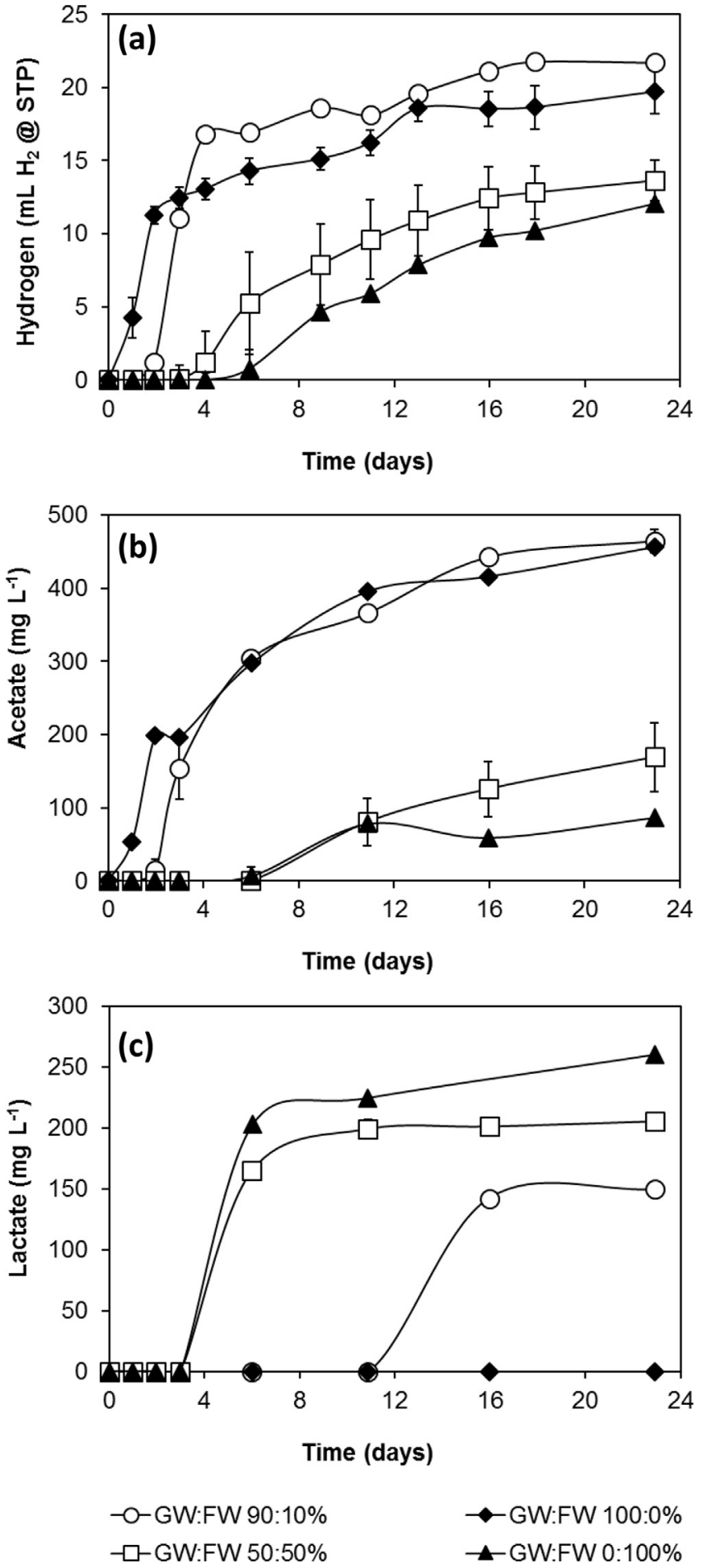

Fig. 2. Biohydrogen production (a), acetate (b) and lactate (c) during the cofermentation of GW and FW.

phase hydrogen-methane producing systems to improve the overall FW conversion yields (Braguglia et al., 2018).

\subsection{Hydrogen production by co-fermentation of FW and GW}

Different ratios of GW and FW (90:10 and 50:50\%) were tested for biohydrogen production and compared with the individual substrates (GW:FW ratios of $100: 0 \%$ and $0: 100 \%$ ), using a final waste concentration (in VS) of $8.5 \mathrm{~g} \mathrm{~L}^{-1}$. Highest cumulative hydrogen production $\left(21.7 \mathrm{~mL} \mathrm{H}_{2}\right)$ was achieved in the assay with $\mathrm{GW}: \mathrm{FW}$ 90:10\%
(Fig. 2a), and the lowest value was obtained from GW:FW 0:100\%. The onset of hydrogen production was delayed in all the assays with FW, being this effect directly related with the FW concentration (Fig. 2a and Table 3), as already described in the biohydrogen production assays made only with FW (Fig. 1a). These results suggest an inhibitory effect of FW on the hydrogen production, possibly associated with the presence of inhibitory by-products released by autoclaving, even though the co-fermentation of GW with small percentage of FW (90:10\%) was beneficial. Higher values of hydrogen production rate and maximum hydrogen production were achieved in this situation (i.e. $21.6 \pm 3.3 \mathrm{~mL} \mathrm{~g}^{-1} \mathrm{~d}^{-1}$ and $46.2 \pm 0.9 \mathrm{mLg}^{-1}, \quad$ respectively) (Table 3). Analysis of the soluble fermentation products showed acetate and lactate accumulation in most assays (Fig. 2b, c). Acetate concentrations followed the hydrogen production trend (Fig. 2b), while higher lactate concentrations were attained for GW:FW 0:100\% and 50:50\% (Fig. 2c). No lactate was formed with only GW (GW:FW 100:0\%). In general, lactate is formed when hydrogen partial pressure $\left(\mathrm{pH}_{2}\right)$ achieves a critical value, the metabolism shifts and NADH is used by lactate dehydrogenase to produce lactate instead of acetate and hydrogen (van de Werken et al., 2008). Different $p \mathrm{H}_{2}$ critical values for C. saccharolyticus have been found, e.g. 10-20 kPa for C. saccharolyticus growing in sucrose (van Niel et al., 2003) and up to $60 \mathrm{kPa}$ when using xylose (Willquist et al., 2010). In the present study, the higher $\mathrm{pH}_{2}$ values attained were $39 \mathrm{kPa}$ and $35 \mathrm{kPa}$, in the GW:FW 90:10\% and 100:0\% assays, respectively (Table 3 ). Unexpectedly, these assays were the ones with lower lactate production, which suggests that lactate formation was not directly related with $\mathrm{pH}_{2}$.

The COD conversion efficiency of the wastes into hydrogen and organic acids, i.e. acetate and lactate (Table 4), was higher in the assays with GW:FW 90:10\%, in which the sum of these products accounted for $49 \%$ and $12 \%$ of the soluble and total COD added (Table 4). In this case, and also in the assay with GW:FW 100:0\%, the hydrogen produced represented $13 \%$ of the soluble COD and $3 \%$ of the total COD, as previously reported (Liu et al., 2013; Algapani et al., 2018; Yun et al., 2018). These results point that co-fermentation of the wastes was not complete, still remaining non-converted soluble COD and non-hydrolyzed waste in the end of the experiment. Moreover, an important amount of the wastes energy remains in the liquid phase as organic acids.

\subsection{Biomethane production assays}

Biomethane was successfully produced from the resulting end-products of the co-fermentation assays (GW:FW 90:10, 100:0 and 0:100\%) (Fig. 3), and no methane was produced in the blanks (with hydrolysate and without sludge). The initial total and soluble COD values were similar in all the conditions tested, i.e. around $15 \mathrm{~g} \mathrm{~L}^{-1}$ and $9 \mathrm{gL}^{-1}$, respectively (Table 3). The highest methane production $(1247 \pm 70 \mathrm{mg}$ COD-CH $\left.{ }_{4}\right)$ and BMP $\left(276.8 \pm 15.4 \mathrm{~L} \mathrm{~kg}^{-1}\right.$ relatively to the substrate COD added) was attained with the end-products of dark fermentation carried out with GW:FW 0:100\% (Fig. 3, Table 3), possibly due to the presence of lactate that might have been used as an alternative source of hydrogen for the hydrogenotrophic methanogens. With the endproducts from GW:FW $90: 10 \%$ and 100:0\%, similar methane production (around $800 \mathrm{mg} \mathrm{COD}-\mathrm{CH}_{4}$ ) and BMP values were obtained (Fig. 3, Table 3), although the presence of $10 \% \mathrm{FW}$ in the first step dark-fermentation increased subsequent initial methane production rate comparatively to $100 \% \mathrm{GW}$ (Fig. 3). When not subjected to the first step of biohydrogen production, the lowest methane production was obtained with a mixture of GW:FW 90:10\% (Fig. 3), thus reinforcing the advantage of combining the two sequential steps. At the end of the experiment, soluble COD removal was approximately the same in all the experiments, ranging from 72 to $77 \%$ (Table 3). Methane production from the soluble end-products of the co-fermentation assays was almost complete, accounting for more than $88 \%$ of the soluble COD, as shown in Table 4. A value higher than $100 \%$ was even attained in the assay 
Table 3

Overall results from biohydrogen production in co-fermentation assays (1st step) coupled with methane production (2nd step).

\begin{tabular}{|c|c|c|c|c|c|c|c|c|c|}
\hline \multirow[t]{2}{*}{ Assay } & \multicolumn{7}{|c|}{ 1st step (Hydrogen Co-Fermentation) } & \multicolumn{2}{|c|}{ 2nd step (Methanogenesis) } \\
\hline & $\begin{array}{l}\text { Maximum } \mathrm{H}_{2} \\
\text { production }(\mathrm{mL} \\
\left.\mathrm{g}^{-1}\right)\end{array}$ & $\begin{array}{l}\mathrm{H}_{2} \text { production } \\
\text { rate }^{*}\left(\mathrm{~mL} \mathrm{~g}^{-1} \mathrm{~d}^{-1}\right)\end{array}$ & Lag phase" (d) & $\mathrm{R}^{2^{* *}}$ & $\begin{array}{l}\text { Maximum } p \mathrm{H}_{2} \\
(\mathrm{kPa})\end{array}$ & $\begin{array}{l}\text { Final } \operatorname{COD}_{t}(g \\
\left.\mathrm{L}^{-1}\right)\end{array}$ & $\begin{array}{l}\text { Final } \mathrm{COD}_{\mathrm{s}} \\
\left(\mathrm{gL}^{-1}\right)\end{array}$ & $\mathrm{BMP}^{* k * k}\left(\mathrm{~L} \mathrm{~kg}^{-1}\right)$ & $\begin{array}{l}\mathrm{COD}_{\mathrm{s}} \text { removal } \\
(\%)\end{array}$ \\
\hline GW:FW 90:10\% & $46.2 \pm 0.9$ & $21.6 \pm 3.3$ & $1.8 \pm 1.2$ & 0.97 & $39.0 \pm 0.2$ & $31.9 \pm 4.8$ & $17.7 \pm 0.5$ & $181.8 \pm 3.8$ & $44.7 \pm 1.7$ \\
\hline GW:FW 50:50\% & $31.3 \pm 1.8$ & $3.0 \pm 0.5$ & $2.6 \pm 0.8$ & 0.96 & $24.5 \pm 2.5$ & - & - & - & - \\
\hline GW:FW 100:0\% & $45.8 \pm 1.2$ & $10.5 \pm 1.9$ & $\approx 0.0$ & 0.95 & $35.3 \pm 2.7$ & $32.2 \pm 1.7$ & $18.2 \pm 0.6$ & $174.3 \pm 23.8$ & $47.9 \pm 1.0$ \\
\hline GW:FW 0:100\% & $16.5 \pm 0.8$ & $2.3 \pm 0.1$ & $4.8 \pm 0.3$ & 0.99 & $12.8 \pm 0.7$ & $31.5 \pm 1.1$ & $19.3 \pm 0.1$ & $276.8 \pm 15.4$ & $53.3 \pm 2.1$ \\
\hline $\begin{array}{l}\text { GW:FW 90:10\% w/ } \\
\text { out } 1 \text { st step }\end{array}$ & - & - & - & - & - & $26.2 \pm 1.6$ & $19.4 \pm 0.4$ & $177.9 \pm 25.4$ & $50.0 \pm 0.8$ \\
\hline
\end{tabular}

* Calculated by adjusting modified Gompertz equation. All parameters are expressed per $g$ of waste VS added initially.

** From data adjustment with modified Gompertz equation.

$* * *$ BMP - Biochemical methane potential, expressed in volume of methane produced (L@STP) per kg of total COD added.

containing only FW (GW:FW 0:100\%), which shows the occurrence of waste solubilization during the experiment, in an amount that corresponds to approximately $16 \%$ of the initial total COD. In the co-digestion of GW:FW 90:10\% performed without previous fermentation by $C$. saccharolyticus, the methane produced represented only $69 \%$ of the soluble COD. Regarding total COD, approximately $50 \%$ was converted to methane in all the assays, with the exception of GW:FW 0:100\% in which the methane produced accounted for $78 \%$ of the total COD (Table 4).

The efficient conversion of organic wastes into biohydrogen and methane, applying two step processes, has been reported by several authors. For example, hydrogen and methane production yields (expressed relatively to the waste VS added) of $105 \pm 55 \mathrm{~mL} \mathrm{~g}^{-1}$ and $526 \pm 137 \mathrm{~mL} \mathrm{~g}^{-1}$, respectively, were attained by Algapani et al. (2018) from $\mathrm{FW}$ in a continuous thermophilic $\left(55^{\circ} \mathrm{C}\right)$-mesophilic $\left(37^{\circ} \mathrm{C}\right)$ two-stage system. Hydrogen and methane accounted for $4 \%$ and $55 \%$ of the total COD in FW, respectively. These authors also showed that the contribution of the hydrogen production step to the overall energy was small, but it played an important role in maintaining the stability of the anaerobic treatment of FW. Concerning lignocellulosic wastes, $\mathrm{Y}_{\mathrm{H} 2}$ and $\mathrm{Y}_{\mathrm{CH} 4}$ of $6 \mathrm{~mL} \mathrm{~g}^{-1}$ and $476 \mathrm{~mL} \mathrm{~g}^{-1}$, respectively, were reported by Pakarinen et al. (2009) from grass silage using a thermophilic-mesophilic two-step process. Kongjan et al. (2011) reported maximum hydrogen and methane yields of $89 \mathrm{~mL} \mathrm{~g}^{-1}$ and $307 \mathrm{~mL} \mathrm{~g}^{-1}$ from wheat straw hydrolysate during the operation of UASB reactors in series. The hydrogen-producing reactor was operated at $70^{\circ} \mathrm{C}$, and subsequent methane reactor at $55^{\circ} \mathrm{C}$.

In summary, the two step hyperthermophilic-mesophilic process applied in the present work allowed the conjugated treatment of GW and FW, with energy recovery in the form of biohydrogen and biomethane, two renewable and eco-friendly fuels. Combining hydrogen and methane production was beneficial because it increased the energy

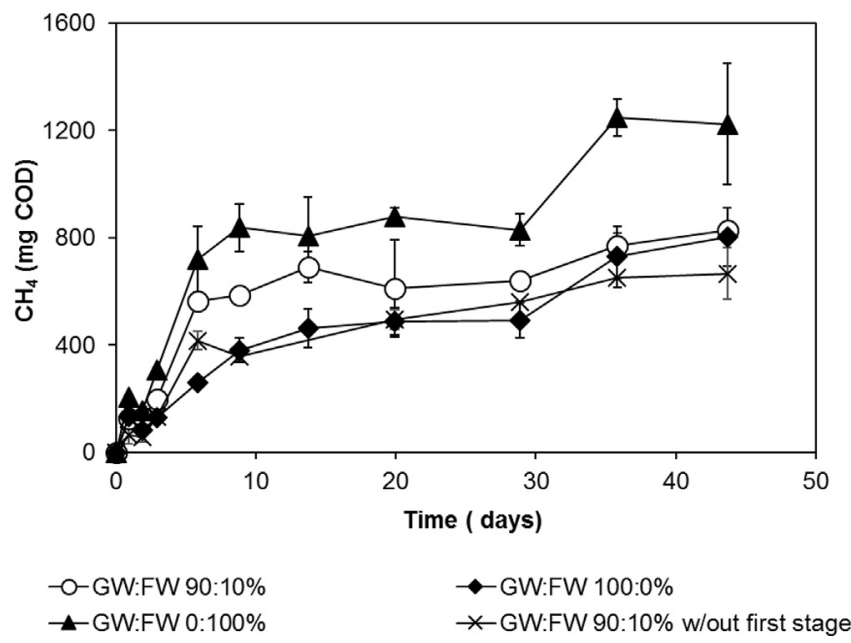

Fig. 3. Methane production from the end-products of the co-fermentation assays.

efficiency of the treatment of both wastes. Indeed, the first fermentation step appears to have facilitated further FW conversion to methane. For $\mathrm{GW}$, the addition of a relatively small amount of FW improved the hydrogen production yield and rate and a significant amount of methane was also produced from this mixture of wastes in the second step. Moreover, more methane was produced in this case than from the same mixture of wastes that was not previously fermented by $C$. saccharolyticus at $70^{\circ} \mathrm{C}$.

Table 4

COD conversion efficiency in the hydrogen co-fermentation of GW and FW (1st step) coupled with methane production (2nd step).

\begin{tabular}{|c|c|c|c|c|c|c|}
\hline \multirow[t]{2}{*}{ Assay } & \multicolumn{4}{|c|}{ 1st step (Hydrogen Co-Fermentation) } & \multicolumn{2}{|c|}{ 2nd step (Methanogenesis) } \\
\hline & $\mathrm{H}_{2}+\mathrm{Ac}+\mathrm{Lac}(\% \mathrm{CODs})^{(\mathrm{a})}$ & $\mathrm{H}_{2}+\mathrm{Ac}+\mathrm{Lac}(\% \mathrm{CODt})^{(\mathrm{a})}$ & $\mathrm{H}_{2}(\% \mathrm{CODs})^{(\mathrm{b})}$ & $\mathrm{H}_{2}(\% \mathrm{CODt})^{(\mathrm{b})}$ & $\mathrm{CH}_{4}(\% \mathrm{CODs})^{(\mathrm{c})}$ & $\mathrm{CH}_{4}(\% \mathrm{CODt})^{(\mathrm{c})}$ \\
\hline GW:FW 90:10\% & 49 & 12 & 13 & 3 & 94 & 52 \\
\hline GW:FW 50:50\% & 25 & 9 & 6 & 2 & - & - \\
\hline GW:FW 100:0\% & 38 & 9 & 13 & 3 & 88 & 50 \\
\hline GW:FW 0:100\% & 18 & 8 & 4 & 2 & 127 & 78 \\
\hline GW:FW 90:10\% w/out 1st step & - & - & - & - & 69 & 51 \\
\hline
\end{tabular}

(a) Represents the relation between the amount of hydrogen, acetate and lactate produced, converted to its equivalent COD, and the amount of soluble COD (CODs) or total COD (CODt) added to each assay.

(b) Represents the relation between the amount of hydrogen produced, converted to its equivalent COD, and the amount of soluble COD (CODs) or total COD (CODt) added to each assay.

(c) Represents the relation between the amount of methane produced, converted to its equivalent COD (considering that $1 \mathrm{~g}$ of COD generates $0.35 \mathrm{~L}$ of methane at STP conditions), and the amount of soluble COD (CODs) or total COD (CODt) added to each assay. 


\section{Conclusions}

Hydrogen and methane production from co-fermentation of GW and FW was successfully attained in a two-stage process. A maximum hydrogen yield of $46.2 \pm 0.9 \mathrm{~L} \mathrm{~kg}^{-1}$ was achieved in the first stage process of dark fermentation with co-fermentation of GW and FW at a ratio of $90: 10 \%$ by C. saccharolyticus. The co-fermentation end-products of GW and FW 90:10\% yielded a maximum methane production of $682 \mathrm{~L} \mathrm{~kg}^{-1}$ in the second stage process of anaerobic digestion. The hydrogen and methane yields obtained in the present study allow a potential total energy generation of $24.9 \mathrm{MJ} \mathrm{kg}^{-1}$.

\section{Acknowledgements}

This study was supported by the Portuguese Foundation for Science and Technology (FCT) under the scope of the strategic funding of UID/ BIO/04469/2013 unit and COMPETE 2020 (POCI-01-0145-FEDER006684), Project SAICTPAC/0040/2015 (POCI-01-0145-FEDER016403) and BioTecNorte operation (NORTE-01-0145-FEDER-000004) funded by the European Regional Development Fund under the scope of Norte2020 - Programa Operacional Regional do Norte. The authors also acknowledge the financial support of FCT and European Social Fund through the grant attributed to A.A. Abreu (SFRH/BPD/82000/2011). Research of A.J. Cavaleiro was supported by the European Research Council under the European Union's Seventh Framework Programme (FP/2007-2013)/ERC Grant Agreement No 323009.

\section{References}

Abreu, A.A., Tavares, F., Alves, M.M., Pereira, M.A., 2016. Boosting dark fermentation with co-cultures of extreme thermophiles for biohythane production from garden waste. Bioresour. Technol. 219, 132-138.

Algapani, D.E., Qiao, W., di Pumpo, F., Bianchi, D., Wandera, S.M., Adani, F., Dong, R., 2018. Long-term bio- $\mathrm{H}_{2}$ and bio- $\mathrm{CH}_{4}$ production from food waste in a continuous two-stage system: energy efficiency and conversion pathways. Bioresour. Technol. 248, 204-213.

Angelidaki, I., Alves, M., Bolzonella, D., Borzacconi, L., Campos, J.L., Guwy, A.J., Kalyuzhnyi, S., Jenicek, P., van Lier, J.B., 2009. Defining the biomethane potential (BMP) of solid organic wastes and energy crops: a proposed protocol for batch assays. Water Sci. Technol. 59, 927-934.

APHA, AWWA, WEF, 1998. Standard Methods for the Examination of Water and Wastewater, 20th ed. American Public Health Association/American Water Works Association/Water Environment Federation, Washington DC.

Arriaga, S., Rosas, I., Alatriste-Mondragón, F., Razo-Flores, E., 2011. Continuous production of hydrogen from oat straw hydrolysate in a biotrickling filter. Int. J. Hydrogen Energy 36, 3442-3449.

Bharathiraja, B., Sudharsanaa, T., Bharghavi, A., Jayamuthunagai, J., Praveenkumar, R., 2016. Biohydrogen and biogas - An overview on feedstocks and enhancement process. Fuel 185, 810-828.

Bielen, A., Verhaart, M., van der Oost, J., Kengen, S., 2013. Biohydrogen production by the thermophilic bacterium Caldicellulosiruptor saccharolyticus: current status and perspectives. Life 3, 52-85.

Bligh, E.G., Dyer, W.J., 1959. A rapid method of total lipid extraction and purification. Can. J. Biochem. Physiol. 37, 911-917.

Boldrin, A., 2009. Environmental Assessment of Garden Waste Management. PhD Thesis. Technical University of Denmark.

Braguglia, C.M., Gallipoli, A., Gianico, A., Pagliaccia, P., 2018. Anaerobic bioconversion of food waste into energy: a critical review. Bioresour. Technol. 248, 37-56.

Cao, G.L., Ren, N.Q., Wang, A.J., Lee, D.J., Guo, W.Q., Liu, B.F., et al., 2009. Acid hydrolysis of corn stover for biohydrogen production using Thermoanaerobacterium thermosaccharolyticum W16. Int. J. Hydrogen Energy 34, 7182-7188.

Cheng, C.-L., Lo, Y.-C., Lee, K.-S., Lee, D.-J., Lin, C.-Y., Chang, J.-S., 2011. Biohydrogen production from lignocellulosic feedstock. Bioresour. Technol. 102, 8514-8523.

Costa, J.C., Oliveira, J.V., Pereira, M.A., Alves, M.M., Abreu, A.A., 2015. Biohythane production from marine macroalga Sargassum sp. coupling dark fermentation and anaerobic digestion. Bioresour. Technol. 190, 251-256.

Datar, R., Huang, J., Maness, P.C., Mohagheghi, A., Czemik, S., Chornet, E., 2007. Hydrogen production from the fermentation of corn stover biomass pretreated with a steam-explosion process. Int. J. Hydrogen Energy 32, 932-939.

De Gioannis, G., Muntoni, A., Polettini, A., Pomi, R., 2013. A review of dark fermentative hydrogen production from biodegradable municipal waste fractions. Waste Manage. $33,1345-1361$.

Elbeshbishy, E., Hafez, H., Nakhla, G., 2011. Ultrasonication for biohydrogen production from food waste. Int. J. Hydrogen Energy 36, 2896-2903.

Eiroa, M., Costa, J.C., Alves, M.M., Kennes, C., Veiga, M.C., 2012. Evaluation of the biomethane potential of solid fish waste. Waste Manage. 32, 1347-1352.

FAO, 2003. Food Energy - Methods of Analysis and Conversion Factor. Food and
Agriculture Organization of the United Nations, Rome, Italy.

Ghimire, A., Trably, E., Frunzo, L., Pirozzi, F., Lens, P.N.L., Esposito, G., Cazier, E.A., Escudié, R., 2018. Effect of total solids content on biohydrogen production and lactic acid accumulation during dark fermentation of organic waste biomass. Bioresour. Technol. 248, 180-186.

Guo, X.M., Trably, E., Latrille, E., Carrère, H., Steyer, J.-P., 2010. Hydrogen production from agricultural waste by dark fermentation: a review. Int. J. Hydrogen Energy 35, 10660-10663.

Hwang, J.-H., Choi, J.-A., Abou-Shanab, R.A.I., Min, B., Song, H., Kim, Y., Lee, E.S., Jeon, B.-H., 2011. Feasibility of hydrogen production from ripened fruits by a combined two-stage (dark/dark) fermentation system. Bioresour. Technol. 102, 1051-1058.

Bioenergy, I.E.A., 2009. Bioenergy - A Sustainable and Reliable Energy Source. Main Report, International Energy Agency, Paris.

Kongjan, P., Angelidaki, I., 2010. Extreme thermophilic biohydrogen production from wheat straw hydrolysate using mixed culture fermentation: Effect of reactor configuration. Bioresour. Technol. 101, 7789-7796.

Kongjan, P., O-Thong, S., Angelidaki, I., 2011. Performance and microbial community analysis of two-stage process with extreme thermophilic hydrogen and thermophilic methane production from hydrolysate in UASB reactors. Bioresour. Technol. 102, 4028-4035.

Li, Y.-C., Wu, S.-Y., Chu, C.-Y., Huang, H.-C., 2011. Hydrogen production from mushroom farm waste with a two-step acid hydrolysis process. Int. J. Hydrogen Energy 36, 14245-14251.

Lin, Y., Wu, S., Wang, D., 2013. Hydrogen-methane production from pulp \& paper sludge and food waste by mesophilic-thermophilic anaerobic co-digestion. Int. J. Hydrogen Energy 38, 15055-15062.

Liu, X., Li, R., Ji, M., Han, L., 2013. Hydrogen and methane production by co-digestion of waste activated sludge and food waste in the two-stage fermentation process: substrate conversion and energy yield. Bioresour. Technol. 146, 317-323.

Lo, Y.C., Lu, W.C., Chen, C.Y., Chang, J.S., 2010. Dark fermentative hydrogen production from enzymatic hydrolysate of xylan and pretreated rice straw by Clostridium butyricum CGS5. Bioresour. Technol. 101, 5885-5891.

Nissilä, M.E., Lay, C.-H., Puhakka, J.A., 2014. Dark fermentative hydrogen production from lignocellulosic hydrolyzates - A review. Biomass Bioenergy 67, 145-159.

Pakarinen, O.M., Tähti, H.P., Rintala, J.A., 2009. One-stage $\mathrm{H}_{2}$ and $\mathrm{CH}_{4}$ and two-stage $\mathrm{H}_{2}$ $+\mathrm{CH}_{4}$ production from grass silage and from solid and liquid fractions of $\mathrm{NaOH}$ pretreated grass silage. Biomass Bioenergy 33, 1419-1427.

Pan, J., Chen, X., Sheng, K., Yu, Y., Zhang, C., Ying, Y., 2013. Effect of ammonia on biohydrogen production from food waste via anaerobic fermentation. Int. J. Hydrogen Energy 38, 12747-12754.

Pawar, S.S., van Niel, E.W.J., 2013. Thermophilic biohydrogen production: how far are we? Appl. Microbiol. Biotechnol. 97, 7999-8009.

Ren, N., Guo, W., Liu, B., Cao, G., Ding, J., 2011. Biological hydrogen production by dark fermentation: challenges and prospects towards scaled-up production. Curr. Opin. Biotechnol. 22, 365-370.

Shi, Y., Ge, Y., Chang, J., Shao, H., Tang, Y., 2013. Garden waste biomass for renewable and sustainable energy production in China: potential, challenges and development. Renew. Sust. Energy Rev. 22, 432-437.

Sivagurunathan, P., Kumar, G., Mudhoo, A., Rene, E.R., Saratale, G.D., Kobayashi, T., Xu, K., Kim, S.-H., Kim, D.-H., 2017. Fermentative hydrogen production using lignocellulose biomass: an overview of pre-treatment methods, inhibitor effects and detoxification experiences. Renew. Sust. Energ. Rev. 77, 28-42.

Sluiter, A., Hames, B., Ruiz, R., Scarlata, C., Sluiter, J., Templeton, D., Nrel, D.C., 2008. Determination of structural carbohydrates and lignin in biomass. Laboratory Analytical Procedure, Technical Report NREL/TP-510-42623. National Renewable Energy Laboratory.

Urbaniec, K., Bakker, R.R., 2015. Biomass residues as raw material for dark hydrogen fermentation - A review. Int. J. Hydrogen Energy 40, 3648-3658.

van de Werken, H.J.G., Verhaart, M.R., VanFossen, A.L., Willquist, K., Lewis, D.L., Nichols, J.D., et al., 2008. Hydrogenomics of the extremely thermophilic bacterium Caldicellulosiruptor saccharolyticus. Appl. Environ. Microbiol. 74, 6720-6729.

van Niel, E.W.J., Claassen, P.A.M., Stams, A.J.M., 2003. Substrate and product inhibition of hydrogen production by the extreme thermophile, Caldicellulosiruptor saccharolyticus. Biotechnol. Bioeng. 81, 255-262.

Wang, X., Zhao, Y., 2009. A bench scale study of fermentative hydrogen and methane production from food waste in integrated two-stage process. Int. J. Hydrogen Energy 34, 245-254.

Wang, J., Bibra, M., Venkateswaran, K., Salem, D.R., Rathinam, N.K., Gadhamshetty, V., Sani, R.K., 2018a. Biohydrogen production from space crew's waste simulants using thermophilic consolidated bioprocessing. Bioresour. Technol. 255, 349-353.

Wang, J., Rathinam, N.K., Salem, D.R., Sani, R.K., 2018b. Integrated consolidated bioprocessing for conversion of lignocellulosic feedstock to biofuels and value-added bioproducts. In: Sani, R.K., Rathinam, N.K. (Eds.), Extremophilic Microbial Processing of Lignocellulosic Feedstocks to Biofuels, Value-Added Products, and Usable Power. Springer International Publishing, pp. 247-273.

Willquist, K., Zeidan, A.A., van Niel, E.W.J., 2010. Physiological characteristics of the extreme thermophile Caldicellulosiruptor saccharolyticus: an efficient hydrogen cell factory. Microb. Cell Fact. 9, 89.

Yasin, N.H.M., Mumtaz, T., Hassan, M.A., Abd Rahman, N., 2013. Food waste and food processing waste for biohydrogen production: a review. J. Environ. Manage. 130, 375-385.

Yun, Y.-M., Lee, M.-K., Im, S.-W., Marone, A., Trably, E., Shin, S.-R., Kim, M.-G., Cho, S.K., Kim, D.-H., 2018. Biohydrogen production from food waste: current status, limitations, and future perspectives. Bioresour. Technol. 248, 79-87.

Zwietering, M.H., Jongenburger, I., Rombouts, F.M., van't Riet, K., 1990. Modeling of the bacterial growth curve. Appl. Environ. Microbiol. 56, 1875-1881. 